\title{
Bagaimanakah Persepsi Keterpercayaan Masyarakat terhadap Elit Politik?
}

\author{
Handrix Chris Haryanto ${ }^{1}$ \\ Tia Rahmania, Ahmad R. Mubarok, Agung B. Dopo, Hafil Fauzi, Erdizal Fajri
}

Program Studi Psikologi Universitas Paramadina

\begin{abstract}
The aim of this study was to identify Jakarta residents' perceptions on the trustworthiness of political elites. The study used qualitative content analysis method involving as many as 461 persons as subjects. These political elites referred to the members of the House of Representatives, members of the People's Consultative Council, the president and the members of his governmental cabinet, political parties, people or groups involved in politics and those participating in managing the state. The top ten factors able to degrade people's trust in political elites were identical with the subjects' perception about lie $(29.28 \%)$, corruption $(14.75 \%)$, selfishness $(8.24 \%)$, incompetence $(6.07 \%)$, scandals $(5.64 \%)$, irresponsibility $(1.95 \%)$, abuse of power $(1.52 \%)$, laziness $(1.52 \%)$, lack of transparency $(1,30 \%)$, and lack of firmness $(0.22 \%)$. The description about political elites worth trusting concerned about their honesty $(39.70 \%)$, accountability $(12.80 \%)$, integrity $(1280 \%)$, caring $(8.89 \%)$, morality $(6.29 \%)$, firmness $(4.34 \%)$, competence $(3.69 \%)$, transparency $(1.74 \%)$, and wisdom $(1.74 \%)$. The study concluded that the trustworthiness of political elites refers to their dispositions that are considered to have good motives and go with any prevailing norms.
\end{abstract}

Keywords: trustworthiness, political elites, trust

Abstrak. Penelitian ini bertujuan untuk mengidentifikasi landasan keterpercayaan terhadap para pihak-pihak yang dianggap sebagai elit politik pada masyarakat Jakarta. Partisipan dalam penelitian berjumlah 461 orang dengan metode kualitatif analisis konten yang menggunakan kuisioner terbuka dan dianalisis menggunakan analisis konten induktif. Hasil penelitian menggambarkan bahwa elit politik ditujukan kepada para anggota Dewan Perwakilan Rakyat, Majelis Permusyawaratan Rakyat, Presiden beserta jajaran kabinetnya, partai politik, orang atau kelompok yang berkecimpung di dunia politik dan pihak-pihak yang mengelola negara. Sepuluh besar faktor yang dapat menurunkan kepercayaan terhadap elit politik identik dengan banyak kebohongan (29,28\%), korupsi (14,75\%), mementingkan diri sendiri $(8,24 \%)$, tidak kompeten $(6,07 \%)$, berkasus $(5,64 \%)$, tidak bertanggung jawab $(1,95 \%)$, menyalahgunakan kekuasaan $(1,52 \%)$, malas $(1,52 \%)$, kurang transparan $(1,30 \%)$, tidak tegas $(0,22 \%)$. Gambaran mengenai elit politik yang dapat dipercaya terkait dengan kejujuran $(39,70 \%)$, tanggung jawab $(12,80)$, integritas $(12,80 \%)$, peduli $(8,89 \%)$, bermoral $(6,29 \%)$, tegas $(4,34 \%)$, kompeten $(3,69 \%)$, transparan $(1,74 \%)$ dan bijaksana $(1,74 \%)$. Hasil tersebut menunjukkan bahwa landasan kepercayaan pada elit politik ditekankan pada keberadaan karakter yang dianggap memiliki motif baik dan erat dengan norma.

Kata kunci: elit politik, karakter keterpercayaan, kepercayaan

\footnotetext{
${ }^{1}$ Korespondensi mengenai isi artikel ini dapat dilakukan melalui: handrix.haryanto@paramadina.ac.id
} 
Keberadaan politik di negeri ini pada dasarnya merupakan objek pembahasan yang tidak akan ada habisnya. Permasalahan mengenai politik dalam hal ini tidak jarang menjadi headline yang selalu menghiasi dalam media massa salah satu diantaranya terkait dengan kepercayaan. Kepercayaan dalam hal ini merupakan hal yang penting dalam kaitannya masyarakat dan politik itu sendiri (Sahaar, 2014). Kepercayaan terhadap politik itu sendiri merupakan suatu kondisi dimana pihakpihak yang dianggap menjalankan pemerintahan ini bisa memenuhi standar keinginan individu atau masyarakatnya (Gamson dalam Kim \& Park, 2005). Pentingnya akan keberadaan sebuah kepercayaan tersebut pula telah dijelaskan oleh beberapa ahli diantaranya adalah Tanis dan Postmes (2005) yang menekankan pada penguatan jalinan interpersonal untuk mendekatkan kepada tujuan yang bersifat konstruktif satu sama lain, Igarashi, et al. (2008), Hardin (2002) dan Faturochman (2000) yang menekankan pada kerjasama serta Blind (2006) yang mengarahkan pada upaya membangun legitimasi serta penopang sistem politik yang akan dibangun kedepannya. Jadi bisa disimpulkan bahwa ketika kepercayaan terhadap politik tidak dapat dibangun dengan baik maka akan memberikan dampak yang negatif terhadap pengelolaan terhadap negara ke depan.

Permasalahan akan kepercayaan terhadap politik ini tidak terlepas dari para pelaku politik itu sendiri. Dalam hal ini keberadaan elit politik menjadi salah satu fokus yang menjadi pusat perhatian. Elit politik seperti halnya dijelaskan oleh Surbakti (1999) merupakan sekelompok kecil orang yang mempunyai pengaruh besar dalam pembuatan dan pelaksanaan keputusan politik. Elit politik dalam hal ini memiliki sumber kekuasaan yang meliputi kekuasaan politik, dan keberadaan elit politik ini sedikit sekali, apabila dibandingkan dengan jumlah penduduk dalam masyarakat negara

Adanya permasalahan mengenai kepercayaan terhadap para elit politik ini diantaranya dilansir oleh hasil survei oleh Lembaga Survei Indonesia (LSI) dan Founding Fathers House (FFH). Saut (2013) menjelaskan hasil survei tahun 2005 yang mencatatkan akan ketidakpercayaan publik terhadap moral elit sebesar 34,6\%. Pada tahun 2009 ketidakpercayaan meningkat menjadi 39,6\% dan kemudian pada tahun 2013 meningkat menjadi $51,5 \%$. Dalam survei yang dilakukan oleh Founding Fathers House (FFH), Hafil (2015) menjelaskan bahwa kepercayaan terhadap partai politik hanya berkisar dari 23\%-29\% dan sekitar $60 \%$ publik tidak percaya dengan partai politik. Kondisi rendahnya tingkat kepercayaan ini menurut peneliti senior FFH tidak terlepas dari perilaku para elit politiknya yang seringkali melakukan perilaku-perilaku penyelesaian konflik yang jauh dari ambang nalar.

Berbicara lebih lanjut mengenai konsep kepercayaan, pada dasarnya telah menjadi salah satu kajian yang dibahas dalam ilmu psikologi. Faturochman (2000) dan Hardin (2002) menggambarkan bahwa kepercayaan ini sering didefinisikan sebagai bentuk pengharapan yang melibatkan keberadaan pihak lain dalam interaksi sosial. Pengharapan ini memiliki risiko yang mengarahkan pada munculnya sebuah konsekuensi negatif ketika harapan yang dimiliki tidak dapat dipenuhi oleh pihak yang dipercaya sehingga memunculkan perasaan dikhianati, kecewa, dan marah (Lewicki \& Brunner dalam Faturochman, 2000). Yamagishi (2011) menjelaskan konsep kepercayaan dengan menekankan pada bentuk keyakinan terhadap pihak lain yang memfokuskan pada kemampuan, niatan maupun reputasi yang baik. 
Dalam konsep kepercayaan pada dasarnya melibatkan pihak yang dipercaya. Di dalam perkembangannya, penekanan akan ciri-ciri sebagai pihak yang dipercaya oleh para ahli dalam perkembangannya ini pada dasarnya memiliki penekanan yang berbeda. Gambaran akan pihak yang dipercaya dapat ditekankan pada sejauh mana upaya memenuhi harapan pihak tertentu dan kebermanfaatannya (Hoffman, 2002; Kramer \& Carnevale dalam Simpson, 2007), terkait dengan karakter yang erat dengan nilainilai moral yang diperlihatkan (Hardin, 2002; Delgado, Frank \& Phelps, 2005; Banerjee, Bowie, \& Pavone, 2006), terkait dengan penggambaran karakter yang mengarah pada sebuah motif yang baik (Yamagishi, 2011), terkait dengan wajah yang terlihat lebih atraktif (mudah tersenyum, terlihat bahagia) dan menyenangkan untuk dilihat (Oosterhof \& Todorov, 2009), maupun terkait dengan sikap terhadap suatu ras (Stanley, Hessner, Banaji, \& Phelps, 2011).

Mendasarkan pada apa yang sudah digambarkan sebelumnya mengenai konsep kepercayaan tersebut, maka upaya untuk mengkaji lebih jauh mengenai gambaran elit politik yang terpercaya khususnya pada masyarakat Kota Jakarta menjadi kajian yang menarik untuk diteliti. Hal ini tidak terlepas dari keberadaan Kota Jakarta yang merupakan pusat pemerintahan dan tidak jarang menjadi barometer dalam perpolitikan nasional (Afrido, 2012).

\section{Metode}

\section{Partisipan Penelitian}

Penelitian ini menggunakan unit analisis individu. Individu yang digunakan dalam penelitian ini merupakan warga Kota Jakarta yang meliputi lima kota- madya (kodya), yaitu Kodya Jakarta Pusat, Kodya Jakarta Barat, Kodya Jakarta Timur, Kodya Jakarta Selatan, Kodya Jakarta Utara dan satu Kabupaten Administrasi Kepulauan Seribu. Partisipan penelitian dalam penelitian ini berjumlah 461 orang yang terdiri dari 283 laki-laki dan 178 perempuan. Usia partisipan dalam penelitian ini berkisar antara 18-61 tahun. Pendidikan partisipan dalam penelitian ini terdiri dari SD (34), SMP (29), SMA (293), D1 (1), D3 (7), S1 (83), S2 (10), S3 (4), tidak sekolah (2) dan tidak mengisi kolom tingkat pendidikan (5).

\section{Metode Penelitian}

Penelitian ini menggunakan metode kualitatif yang berupa analisis isi. Kualitatif analisis isi merupakan metode penelitian kualitatif yang mencoba untuk melihat sebuah makna secara subyektif dari data yang bersifat tekstual melalui sebuah proses klasifikasi koding yang sistematis dan mengidentifikasi tema maupun struktur yang terdapat dalam data tekstual tersebut (Hsieh \& Shannon, 2005). Sandelowski dan Barroso (2003) menjelaskan bahwa keberadaan kualitatif analisis isi ini pada dasarnya merupakan metode penelitian yang sejalan dengan pendekatan grounded theory yang bersifat bottom up. Kemudian teknik pengumpulan sampel yang digunakan dalam penelitian ini adalah convenience sampling. Pengambilan sampel secara convinience mengarahkan pada pengambilan sampel secara nonrandom (Hultsch, MacDonald, Hunter, Maitland, \& Dixon, 2002; Onwuegbuzie \& Collins, 2007). Pemilihan metode pengambilan sampel ini dikarenakan pada saat proses penelitian tidak semua sampel mau mengisi kuisioner dan bersedia menjadi kuisioner. Kriteria sampel di dalam penelitian ini yakni: (1) warga Jakarta, termasuk kedalam lima kotamadya dan satu 
kabupaten. (2) Sudah berumur 17 (tujuh belas) tahun atau sudah/pernah kawin (UU Pemilu), dan (3) Memiliki KTP Jakarta.

\section{Instrumen pengumpulan data}

Instrumen pengumpulan data yang digunakan dalam penelitian ini adalah kuisioner terbuka yang memungkinkan partisipan menjawab dengan mempergunakan kata-kata atau kalimat sendiri. Kuisioner terbuka dalam hal ini dapat digunakan sebagai salah satu alat pengumpulan data dalam penelitian kualitatif analisis konten (Hancock, Okleford, \& Windridge, 2007). Kuisioner terbuka yang dibuat mendasarkan pada pertanyaan-pertanyaan penelitian dalam hal ini berupa: (1) Siapakah elit politik itu? (2) Apa yang bisa menyebabkan kepercayaan terhadap para elit politik menurun? dan (3) Apa yang harus dimiliki oleh para elit politik untuk bisa dipercaya?

\section{Analisis Data}

Data yang terkumpul berdasar pada pertanyaan terbuka kemudian dianalisis menggunakan analisis konten induktif. Penggunaan analisis konten induktif ini merupakan upaya untuk membangun kesimpulan berdasarkan pada jawaban yang dimunculkan oleh partisipan dibandingkan untuk melakukan pembuktian atas teori yang sudah ada sebelumnya (Ello \& Kyngäs, 2008). Ello dan Kyngäs (2008), menggambarkan bahwa di dalam melakukan analisis konten induktif peneliti diarahkan untuk melakukan tiga tahapan pemrosesan data yaitu open coding, kategorisasi, dan abstraksi. Tahap open coding merupakan tahapan awal yang mengarahkan peneliti untuk memberikan satu catatan-catatan tertentu sebagai bentuk pengkodean pada jawaban partisipan. Dalam tahap kategorisasi, peneliti mem- buat sebuah kategori-kategori yang masih bersifat bebas terhadap jawaban para partisipan. Pembuatan kategori-kategori ini mendasarkan pada kemampuan peneliti untuk mendapatkan kata kunci dari jawaban yang telah dituliskan oleh partisipan. Pembuatan kategori-kategori ini pada awalnya masih bersifat bebas tanpa melakukan pengelompokan terlebih dahulu. Setelah proses kategorisasi awal tersebut, selanjutnya peneliti melakukan pengelompokan kategori-kategori tersebut menjadi kategori yang lebih besar dengan mendasarkan pada persamaan maupun perbedaan yang ada dalam kategori-kategori sebelumnya. Dalam tahap abstraksi peneliti akan membuat suatu deskripsi umum yang merupakan hasil dari penggambaran model maupun konsep berdasar pada kategori-kategori yang sudah didapatkan sebelumnya.

Dalam proses analisis data yang sudah dilakukan, keberadaan validitas dan reliabilitas dalam penelitian kualitatif analisis isi dapat menggunakan standar yang biasa digunakan dalam penelitian kualitatif pada umumnya (Cho \& Lee, 2014). Dalam penelitian ini, validitas dan reliabilitas yang digunakan mengacu pada konsep yang dijelaskan oleh Creswell (2005) yaitu berupa peer debriefing dan intercoder agreement. Dalam pelaksanaan peer debriefing ini proses dan hasil penelitian yang diperoleh telah dilakukan review oleh empat dosen yang memiliki kompetensi terkait dengan penelitian yang dilakukan. Intercoder agreement dalam penelitian ini dilakukan dengan melakukan pemeriksaan kembali antar peneliti terkait dengan hasil pengkodean terkait jawaban yang diberikan partisipan. Antar peneliti dalam hal memiliki kesepakatan yang sama terkait dengan hasil tema yang diperoleh atas jawaban partisipan. 


\section{H a s i 1}

Gambaran partisipan mengenai siapakah elit politik



Gambar 1. Gambaran partisipan mengenai siapakah elit politik

Berdasarkan Gambar 1, jawaban partisipan mengenai siapakah elit politik, elit politik adalah legislatif dan konstitutif $(20,17 \%)$; legislatif $(19,96 \%)$; partai politik $(12,15 \%)$; eksekutif $(11,06 \%)$; partai politik, legislatif dan konstitutif (4,77\%); legislatif, eksekutif dan konstitutif $(2,17 \%)$; partai politik dan legislatif (2,17\%); konstitutif $(1,95 \%)$; legislatif dan eksekutif $(1,52 \%)$; legislatif dan yudikatif $(1,30 \%)$; legislatif, eksekutif dan yudikatif (0,87\%); eksekutif dan konstitutif (0,43\%); parpol dan konstitutif $(0,43 \%)$; yudikatif $(0,43 \%)$; parpol, legislatif, eksekutif dan konstitutif $(0,43 \%)$; yudikatif, parpol, legislatif dan konstitutif $(0,43 \%)$; parpol dan eksekutif $(0,43 \%)$; parpol, legislatif dan eksekutif $(0,22 \%)$; parpol, legislatif dan yudikatif $(0,22 \%)$. Sisanya sebesar $18,87 \%$ partisipan memberikan jawaban yang tidak relevan serta tidak melakukan pengisian pada kolom yang disediakan. 
Faktor-faktor penyebab yang dapat menurunkan kepercayaan terhadap elit politik

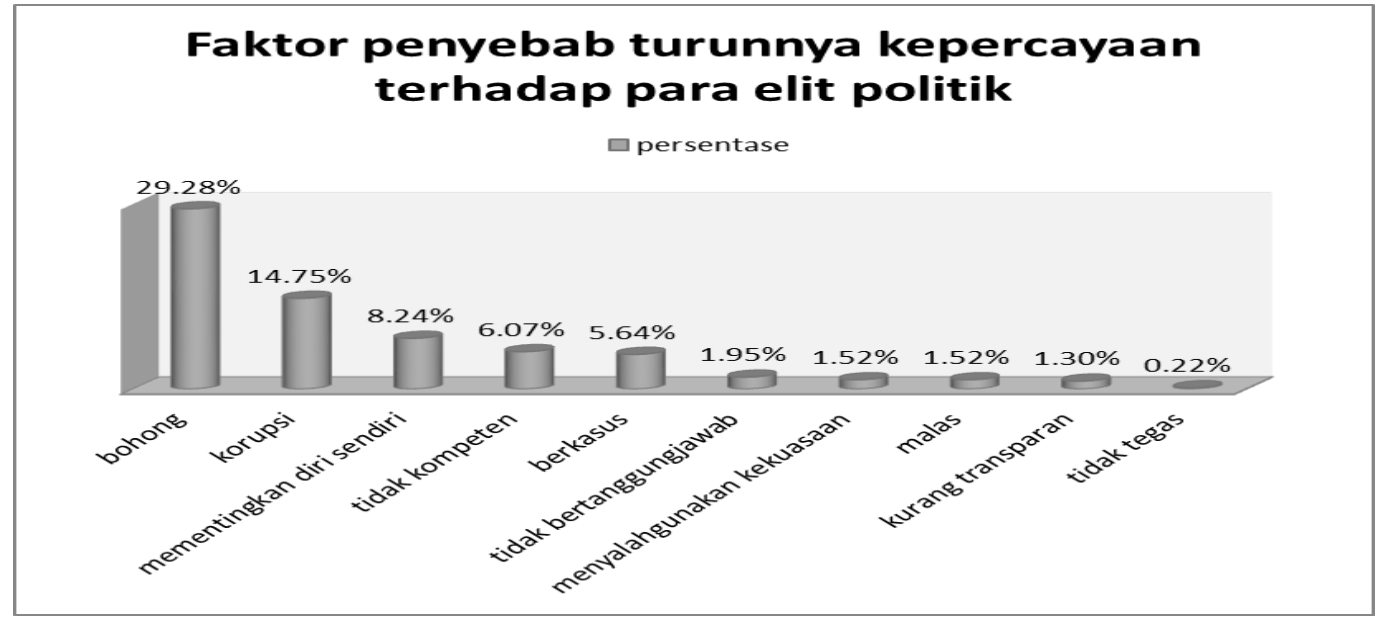

Gambar 2. Faktor-faktor penyebab menurunnya kepercayaan terhadap elit politik

Tabel 1

Subkategori faktor-faktor penyebab yang dapat menurunkan kepercayaan terhadap elit politik

\begin{tabular}{lc}
\hline Kategori & Total \\
\hline Bohong & $\mathbf{1 3 5}^{\mathbf{1}(\mathbf{2 9 . 2 8})^{\mathbf{2}}}$ \\
Bohong & $122(26.46)$ \\
Tidak jujur & $8(1.73)$ \\
Palsu & $5(1.09)$ \\
Korupsi & $\mathbf{6 8}(\mathbf{1 4 . 7 5 )}$ \\
Korupsi & $68(14.75)$ \\
Mementingkan diri sendiri & $\mathbf{3 8}(\mathbf{8 . 2 4 )}$ \\
Mementingkan diri sendiri & $17(3.69)$ \\
Memikirkan kepentingan sendiri & $12(2.60)$ \\
Tidak mewakili rakyat & $9(1.95)$ \\
Tidak kompeten & $\mathbf{2 8 ( 6 . 0 7 )}$ \\
Tidak kompeten & $23(4.99)$ \\
Tidak becus bekerja & $5(1.08)$ \\
Berkasus & $\mathbf{2 6}(5.64)$ \\
Berkasus & $16(3.48)$ \\
Banyak masalah & $5(1.08)$ \\
Terjerat kasus & $3(0.65)$ \\
Tersangka masalah hukum & $2(0.43)$ \\
Tidak bertanggungjawab & $\mathbf{9 ( 1 . 9 5 )}$ \\
Tidak bertanggungjawab & $6(1.30)$ \\
Tidak amanah & $3(0.65)$ \\
Menyalahgunakan kekuasaan & $\mathbf{7 ( 1 . 5 2 )}$ \\
Menyalahgunakan kekuasaan & $5(1.09)$ \\
Menyelewengkan kekuasaan & $2(0.43)$ \\
\hline
\end{tabular}

\begin{tabular}{|c|c|}
\hline Malas & 7 (1.52) \\
\hline Malas & $7(1.52)$ \\
\hline Kurang transparan & $6(1.30)$ \\
\hline Kurang transparan & $4(0.86)$ \\
\hline Tidak terbuka & $2(0.44)$ \\
\hline Tidak tegas & $1(0.22)$ \\
\hline Tidak tegas & $1(0.22)$ \\
\hline Others & $136(29.50)$ \\
\hline Tidak relevan & 88 (19.09) \\
\hline Blank & $48(10.41)$ \\
\hline Total & $461(100)$ \\
\hline
\end{tabular}

Berdasarkan Gambar 2, faktor-faktor penyebab yang menjadikan kepercayaan terhadap elit politik menurun terkait dengan persepsi partisipan terhadap elit politik yang identik dengan kebohongan $(29,28 \%)$; korupsi $(14,75 \%)$; mementingkan diri sendiri $(8,24 \%)$; tidak kompeten $(6,07 \%)$; berkasus $(5,64 \%)$; tidak bertanggung jawab (1,95\%); menyalahgunakan kekuasaan $(1,52 \%)$; malas $(1,52 \%)$; kurang transparan $(1,30 \%)$; tidak tegas $(0,22 \%)$. Untuk kategori terakhir berupa others sebesar $29,50 \%$ yang terdiri dari jawabanjawaban partisipan yang tidak relevan dengan pertanyaan penelitian maupun yang tidak memberikan jawaban terhadap pertanyaan yang diberikan. 
Berdasarkan Gambar 3, dapat dilihat bahwa ketidakpercayaan terhadap elit politik berdasarkan pada faktor kebohongan yang masuk dalam tiga besar diarahkan pada tiga pihak elit politik yaitu legislatif dan konstitutif $(8.46 \%)$, legislatif (6,51\%) dan parpol (2,82\%). Pada faktor korupsi konteks ketidakpercayaan terhadap elit politik diarahkan pada legislatif $(3,25 \%)$, parpol $(2,85 \%)$ serta legislatif dan konstitutif $(2,85 \%)$. Pada faktor mementingkan diri sendiri para partisipan mengarahkan pada legislatif $(1,52 \%)$, parpol $(1,30 \%)$, dan eksekutif $(0,87 \%)$. Pada faktor tidak kompeten diarahkan pada pihak legislatif $(2,39 \%)$, eksekutif $(1,08 \%)$ dan parpol $(0,87 \%)$. Untuk faktor banyaknya Gambaran ketidakpercayaan terhadap elit politik kasus diarahkan pada pihak parpol $(1,08 \%)$, eksekutif $(0,87 \%)$ dan legislatif $(0,87 \%)$. Pada faktor tidak bertanggungjawab diarahkan pada pihak eksekutif $(0,65 \%)$, pihak legislatif dan konstitutif $(0,65 \%)$ serta legislatif $(0,22 \%)$. Pada faktor menyalahgunakan kekuasaan diarahkan pada pihak parpol $(0,22 \%)$, legislatif, eksekutif dan konstitutif $(0,22 \%)$ serta legislatif dan eksekutif $(0,22 \%)$. Untuk faktor malas diarahkan pada pihak legislatif dan konstitutif $(0,65 \%)$, parpol, legislatif dan konstitutif $(0,22 \%)$ serta legislatif dan parpol $(0,22 \%)$. Untuk faktor kurang transparan diarahkan pada pihak parpol $(0,65 \%)$. Pada faktor kurang tegas diarahkan pada pihak eksekutif $(0,22 \%)$.

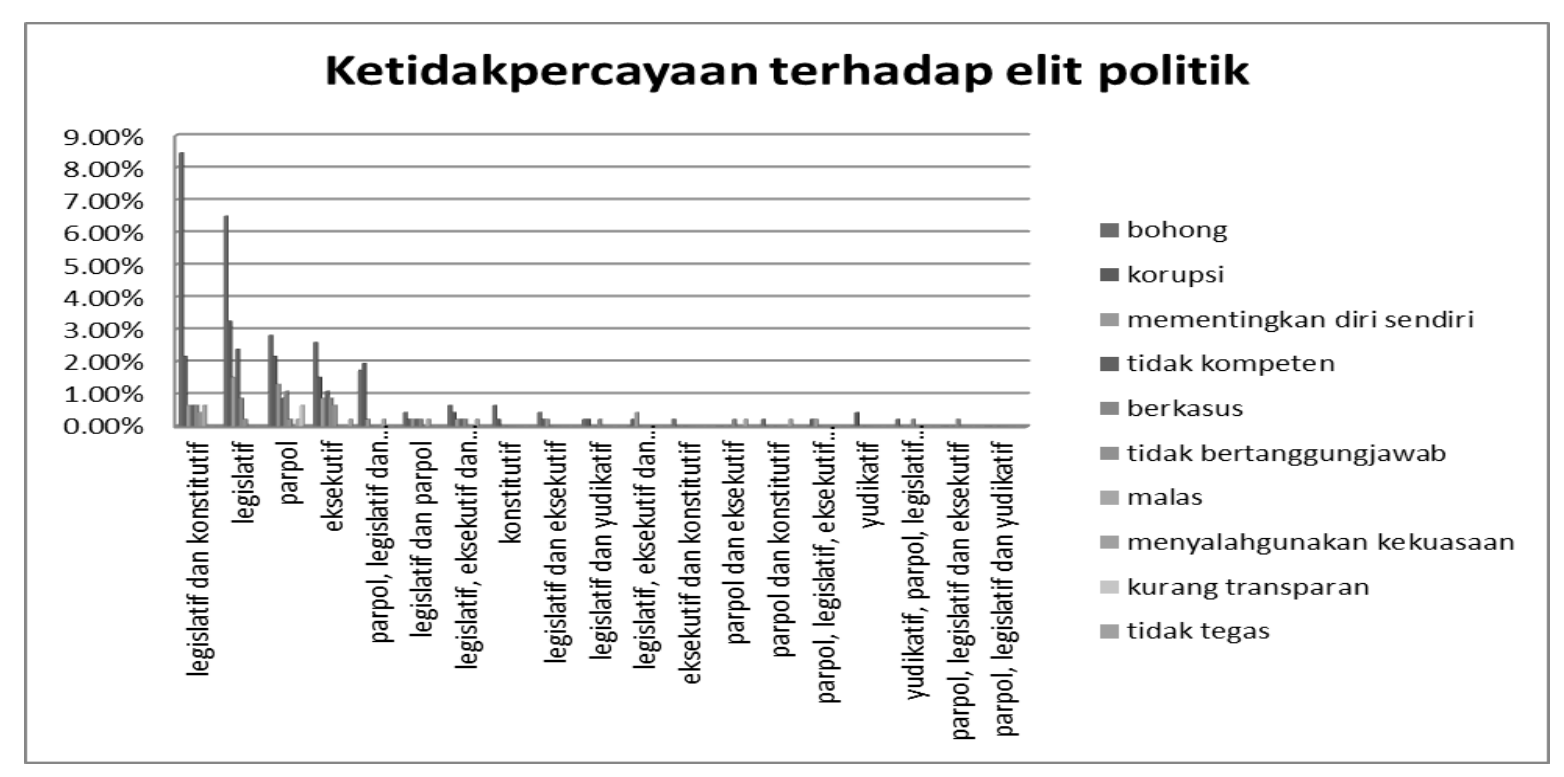

Gambar 3. Ketidakpercayaan terhadap elit politik.

Gambaran karakter elit politik yang dapat dipercaya 
peduli $(8,89 \%)$; bermoral $(6,29 \%)$; tegas $(4,34 \%)$; kompeten $(3,69 \%)$; transparan $(1,74 \%)$ dan bijaksana $(1,74 \%)$. Untuk kategori others sebesar 8,01\% merupakan kategori yang terdiri dari jawabanjawaban partisipan yang tidak relevan dengan pertanyaan penelitian dan partisipan yang tidak memberikan jawaban.

\section{Diskusi}

Ketidakpercayaan terhadap para elit politik didasari oleh persepsi responden pada para elit politik yaitu pada posisi pertama, tingkat ketidakpercayaan terhadap elit politik tergantung pada sejauh mana elit politik dianggap sebagai pihak yang banyak melakukan kebohongan. Permasalahan mengenai ketidakpercayaan terhadap para elit politik akibat faktor kebohongan pada hasil penelitian ini secara khusus diarahkan pada pihak legislatif dan konstitutif $(8.46 \%)$, legislatif (6,51\%) dan parpol (2,82\%). Pihak legislatif (DPR, DPRD dan DPD) ini sendiri mendapatkan porsi persentase yang besar untuk faktor kebohongan dibandingkan kedua pihak yang lain.

Permasalahan akan kebohongan tidak terlepas dari pengingkaran akan janji yang sering terjadi dalam konteks politik. Hal ini menurut Bies dan Triep (Faturochman, 2000) pengingkaran terhadap janji yang sudah dibuatnya merupakan bentuk pelanggaran kepercayaan yang berkaitan dengan civic order. Pengingkaran janji termasuk dalam pelanggaran nilai-nilai sosial khususnya berkaitan dengan kondisi melukai kehormatan yang seharusnya dipenuhi oleh orang yang sudah dipercaya sebelumnya. Solomon dan Flores (2001) menjelaskan bahwa dalam konteks kepercayaan keberadaan akan kebohongan berkaitan dengan label adanya kecurangan dan dianggap tidak memiliki bentuk kepedulian terhadap pihak yang merasa dibohongi. Kebohongan dalam konteks politik menurut Isotalus dan Amonkari (2014) mengarahkan pada gambaran adanya permasalahan yang melibatkan politikus itu sendiri. Hal tersebut, pada dasarnya akan memengaruhi tingkat persepsi publik terhadap kredibilitas yang dimiliki oleh seorang politikus. Faktor kebohongan sebagai faktor yang pertama dapat menurunkan kepercayaan terhadap elit politik ini menunjukkan bahwa para partisipan sangat mengutamakan adanya pemenuhan janji maupun pemenuhan kehormatan bagi para elit politik di dalam menjalankan tugasnya. Permasalahan mengenai kebohongan ini juga terlihat dari salah satu jawaban partisipan berupa "sudah terlalu banyak membohongi masyarakat dengan janji-janji yang palsu".

Korupsi menjadi faktor kedua terbesar yang dapat menurunkan kepercayaan terhadap para elit politik. Permasalahan korupsi sebagai salah satu faktor yang dapat menurunkan kepercayaan terhadap elit politik pada penelitian ini diarahkan pada pihak legislatif $(3,25 \%)$, parpol $(2,85 \%)$ serta legislatif dan konstitutif $(2,85 \%)$. Pihak legislatif dalam hal ini mendapatkan porsi penilaian yang lebih besar dibandingkan pihak parpol dan konstitutif.

Van de Walle (2008); Solé-Ollé dan Sorribas-Navarro (2014) menjelaskan bahwa keberadaan persepsi mengenai korupsi yang terjadi di pemerintah akan memengaruhi bagaimana sikap masyarakat terkait dengan kepercayaan terhadap pemerintahan maupun para politisi lokal. Chang dan Chu (2006); Morris dan Klesner (2010) juga menggambarkan bahwa kepercayaan ini berkaitan dengan pandangan akan kapabilitas pemerintah di dalam memenuhi apa yang masyarakat butuhkan dan inginkan. Hal tersebut tidak terlepas 
dari pemahaman di masyarakat bahwa korupsi hanya mengarahkan pada konteks ketidakadilan dan ketidaksetaraan (Chang \& Chu, 2006). Ketika korupsi banyak merajalela pada tingkat elit politik, maka kekuasaan yang dimiliki hanya memberikan manfaat dan kemudahan bagi para diri sendiri maupun kelompoknya. Salah satu jawaban partisipan mengenai kategori korupsi berupa "kondisi negara saat ini hancur, banyak elit politik yang korupsi".

Pada posisi ketiga, berkaitan dengan kepedulian. Permasalahan kepedulian sebagai salah satu faktor yang dapat menurunkan kepercayaan terhadap elit politik pada penelitian ini diarahkan pada pihak legislatif $(1,52 \%)$, parpol $(1,30 \%)$, dan eksekutif $(0,87 \%)$. Kepedulian seperti halnya digambarkan dalam studi yang dilakukan oleh Dalton (2005) menjadi salah satu hal yang erat kaitannya dengan kepercayaan terhadap sistem politik maupun pemerintahan.

Viklund dan Sjöberg (2008) menerangkan bahwa ketika berbicara mengenai rasa kepedulian dalam kaitannya dengan kepercayaan, individu akan dihadapkan dengan sebuah penilaian moral yaitu adanya ketidakpedulian berarti dianggap tidak bermoral. Faturochman (2000) memberikan penilaian bahwa keberadaan kepedulian erat kaitannya dengan konteks keadilan sosial. Konteks keadilan sosial ini mengarahkan pada upaya untuk tidak hanya memenuhi kepentingan pribadinya, akan tetapi juga kepentingan orang lain. Para elit politik dalam hal ini dianggap sebagai pihak yang memiliki kekuasaan untuk memberikan manfaat bagi orang lain khususnya masyarakat. Salah satu jawaban partisipan terkait kategori mementingkan diri sendiri pada elit politik yaitu "para elit politik sekarang hanya memikirkan diri sendiri, bukan rakyat kebanyakan".
Pada posisi keempat, berkaitan dengan faktor kompetensi. Permasalahan kompetensi sebagai salah satu faktor yang dapat menurunkan kepercayaan terhadap elit politik pada penelitian ini diarahkan pada pihak legislatif (2,39\%), eksekutif $(1,08 \%)$ dan parpol (0,87\%). Kompetensi merupakan salah satu aspek yang dapat memengaruhi tingkat kepercayaan pada satu pihak (Twyman, Harvey, \& Harries, 2008). Kompetensi yang baik pada para politikus mengarahkan tingginya legitimasi masyarakat terhadap politik itu sendiri (Blind, 2006). Neumann, Srbljinović, dan Schatten (2014) menjelaskan bahwa pada konteks politik, keberadaan kompetensi merupakan salah satu indikator untuk melihat seberapa jauh kemampuan yang dimiliki oleh seorang politikus yang salah satunya di dalam mengahadapi kondisi yang krisis. Salah satu jawaban partisipan terkait kategori kompetensi pada elit politik yaitu "kompetensi yang dimiliki oleh para elit politik belum dapat menunjukkan hasil yang baik".

Pada posisi kelima mengarahkan pada sejauh mana para elit politik dinilai sebagai pihak yang selalu berkasus atau mendapatkan permasalahan yang ada baik bersifat sosial maupun hukum. Permasalahan mengenai persepsi elit politik sebagai pihak yang banyak berkasus ini diarahkan pada pihak parpol $(1,08 \%)$, eksekutif $(0,87 \%)$ dan legislatif $(0,87 \%)$. Kondisi tersebut menurut Faturochman (2000) mengarahkan pada bentuk pelanggaran kepercayaan yang berupa pelanggaran terhadap civic order yang mengarah pada manipulasi maupun pengingkaran dan pelanggaran terhadap aturan. Permasalahan akan politisi yang sering tersangkut skandal atau permasalahan juga dianggap telah melakukan pelanggaran norma, tidak memiliki harga diri, disintegritas, mencoreng nama baik (Isotalus \& 
Almonkari, 2014) dan moral yang menggambarkan seorang politisi hanya mementingkan kepentingannya pribadi serta tidak peduli akan kebutuhan masyarakat ketika banyak terlibat masalah atau pelanggaran (Jainuri, 2013). Salah satu jawaban partisipan mengenai kategori berkasus yaitu "banyak elit politik yang tersangkut masalah hukum".

Pada posisi keenam terkait dengan faktor persepsi akan tanggung jawab. Permasalahan mengenai persepsi dalam pemenuhan tanggung jawab sebagai salah satu faktor yang dapat menurunkan kepercayaan pada penelitian ini diarahkan pada pihak eksekutif $(0,65 \%)$, pihak legislatif dan konstitutif $(0,65 \%)$ serta legislatif $(0,22 \%)$. Ketika para pelaku politik dianggap tidak bertanggung jawab atas apa yang seharusnya dilaksanakan, maka dapat dianggap melakukan pelanggaran civic order (Bies \& Triep dalam Faturochman, 2000). Bentuk pemenuhan tanggung jawab yang sesuai dengan tugasnya diimplementasikan dalam bentuk memunculkan perilaku dan peran yang sesuai dengan tuntutan yang ada serta menjalankan dengan baik sistem yang sudah disepakati. Konteks bertanggung jawab dalam politik ini bermuara pada pemenuhan kebutuhan masyarakat (Diamond, 2007). Salah satu jawaban partisipan mengenai kategori tidak bertanggung jawab adalah "tugasnya masih belum dilaksanakan dengan penuh tanggung jawab".

Pada posisi ketujuh, terkait dengan persepsi penyalahgunaan kekuasaan yang dilakukan. Pada faktor menyalahgunakan kekuasaan para elit politik yang dapat menurunkan kepercayaan diarahkan pada pihak parpol $(0,22 \%)$, legislatif, eksekutif dan konstitutif $(0,22 \%)$ serta legislatif dan eksekutif (0,22\%). Diamond (2007) menjelaskan bahwa penyalahgunaan kekuasaan merupakan bentuk pelanggaran terhadap kepercayaan publik. Bentuk pelanggaran ini mengarahkan pada upaya bertindak melampaui wewenang yang seharusnya dan tidak sesuai dengan tujuan yang seharusnya. Penyalahgunaan wewenang dalam dunia politik atau pemerintahan mengarahkan pada kondisi tidak terpenuhinya kebutuhan masyarakat (Diamond, 2007) dan akan mengurangi tingkat legitimasi politik yang diberikan oleh masyarakat (Wångmar dalam Dymek, 2015). Salah satu jawaban partisipan mengenai kategori penyalahgunaan kekuasaan berupa "terlalu banyak yang menyalahgunakan kekuasaan sehingga sulit percaya begitu saja".

Pada posisi kedelapan, terkait faktor persepsi kemalasan. Penekanan faktor kemalasan pada para elit politik ditujukan pada pihak legislatif dan konstitutif $(0,65 \%)$, parpol, legislatif dan konstitutif $(0,22 \%)$ serta legislatif dan parpol $(0,22 \%)$. Persepsi mengenai kemalasan tidak terlepas dari persepsi kerja keras yang dilakukan. Menurut Christensen dan Laegreid (2002) keberadaan kepercayaan terhadap politik ini tidak terlepas dari sejauh mana pemerintahan bekerja untuk masyarakatnya. Galston dan Kamarck (2008) menambahkan bahwa keberadaan para politisi maupun pemerintahan yang dipersepsikan memiliki nilai bekerja keras akan menumbuhkan kepercayaan di masyarakat. Kerja keras tersebut memberikan gambaran bahwa pemerintahan selalu berusaha memenuhi kebutuhan masyarakatnya. Gambaran akan penilaian-penilaian para elit politik yang malas tersebut menjadi salah satu faktor yang memengaruhi persepsi tingkat kepercayaan yang dimiliki. Salah satu jawaban partisipan mengenai kategori malas adalah "masih banyak yang terlihat malas untuk menyelesaikan tugasnya". 
Pada posisi kesembilan, faktor yang dapat menurunkan kepercayaan terhadap para elit politik berkaitan dengan persepsi tidak transparannya para elit politik. Permasalahan transparansi ini ditujukan pada pihak parpol (0,65\%). Keberadaan transparansi yang terkait dengan partai politik merupakan hal yang sangat penting dalam meningkatkan kepercayaan masyarakat terhadap sistem politik maupun sistem berdemokrasi yang ada serta dapat meningkatkan keterlibatan masyarakat dalam politik (Van Biezen, 2003). Transparansi yang dibutuhkan dalam konteks partai politik dalam hal ini berupa keterbukaan informasi pada publik terkait calon yang akan dipilihnya dalam pemerintahan (antikorupsi.org, 2015) maupun laporan keuangan terkait dengan donasidonasi, biaya yang dikeluarkan serta aset yang dimiliki (Hanan, 2015). Popescu (2015) menjelaskan lebih lanjut bahwa ketika transparansi dalam partai politik tidak dapat dimunculkan dengan baik, maka keberadaan adanya penyimpangan dalam konteks korupsi juga dapat terjadi sehingga kepercayaan dalam publik akan menurun, legitimasi terhadap pemerintah yang terpilih akan berkurang dan meningkatkan ketidakpercayaan terhadap sistem demokrasi yang ada. Salah satu jawaban partisipan mengenai kategori tidak transparan adalah "sering beredarnya isu-isu mengenai elit politik khususnya permasalahan transparansi".

Pada posisi kesepuluh, terkait dengan faktor ketidaktegasan. Faktor ketidaktegasan terkait ketidakpercayaan pada elit politik ditujukan pada pihak eksekutif $(0,22 \%)$. Ketegasan menjadi hal yang penting dalam menjalankan pemerintahan khususnya terkait penilaian dari masyarakat. Ketegasan dalam dinamika pemerintahan maupun politik memberikan gambaran akan kemampuan maupun kompetensi untuk mengambil keputusan dengan baik (Hamilton dalam Light, 2007; Levi, 2015). Hal tersebut memberikan persepsi terhadap masyarakat mengenai sejauh mana pemerintah dapat menyelesaikan permasalahan yang mengarah pada manfaat. Salah satu jawaban partisipan mengenai kategori tidak tegas adalah "kebanyakan cuma ngomong saja sok tegas padahal nyatanya tidak".

Selain adanya faktor-faktor yang dapat menurunkan tingkat kepercayaan, maka upaya untuk membangun sebuah gambaran elit politik yang terpercaya berdasarkan pada hasil penelitian harus disandarkan pada sembilan hal yaitu akan kejujuran, tanggung jawab, integritas, peduli, bermoral, tegas, kompeten, transparan dan bijaksana. Gambaran seorang elit politik yang dapat dipercaya menurut para partisipan tersebut erat kaitannya dengan penekanan kepercayaan terhadap karakter yang mengarah pada sebuah motif atau tujuan yang baik (Yamagishi, 2011) dan norma (Hardin, 2002; Delgado, et al., 2005, Banerjee, et al., 2006). Penggambaran sebuah karakter yang dianggap memiliki motif atau tujuan yang baik ditekankan oleh Yamagishi (2011) dengan menggambarkan karakter perilaku yang sesuai dengan moral serta normanorma yang berlaku di masyarakat dan Mayer, et al. (Colquitt, Scott \& LePine, 2007) menjelaskannya dengan tiga karakter yaitu pertama, kemampuan, kebajikan dan integritas. Kemampuan merupakan sekumpulan akan keahlian, kompetensi, maupun karakteristik yang dapat dijadikan dasar penilaian dan memungkinkan pihak yang dipercaya dapat memberikan pengaruh. Kebajikan menggambarkan pada sebuah penilaian bahwa seseorang yang dipercaya akan melakukan hal yang baik dengan tidak terlalu mengedepankan ego dalam 
dirinya. Dalam karakter kebajikan terdiri dari komponen-komponen karakter kesetiaan, keterbukaan, kepedulian atau dukungan Integritas menggambarkan pada karakter sebuah pihak yang dapat dipercaya memiliki prinsip-prinsip yang dapat diterima. Dalam karakter integritas sangat erat dengan prinsip moral dan etika yang dimiliki oleh pihak yang dipercaya. Karakter integritas ini memiliki komponen-komponen kejujuran, keadilan, konsistensi, dan pemenuhan akan janji.

Selain penggambaran yang mengedepankan sebuah motif yang baik, kepercayaan pada elit politik juga dibangun berdasar pada karakter yang melandaskan pada moral. Seperti halnya dijelaskan oleh Hardin (2002) bahwa keberadaan moral menjadi dimensi yang tidak bisa dilepaskan dalam konteks keterpercayaan. Keberadaan moral mengarahkan pada satu gambaran apa yang seharusnya dilakukan sesuai dengan norma maupun aturan yang ada. Delgado, et al. (2005) menambahkan bahwa pihak yang mampu menunjukkan sebuah karakter moral yang baik akan lebih mudah mengajak pihak lain untuk bekerjasama.

\section{Kesimpulan}

Berdasarkan pada hasil penelitian menunjukkan bahwa di dalam ranah politik khususnya kepercayaan terhadap para elit politik harus dibangun dengan karakter-karakter yang terlihat memiliki motif yang baik dan erat dengan norma. Hal ini terlihat dari penilaian partisipan mengenai elit politik yang dapat dipercaya dengan penggambaran karakter-karakter berupa kejujuran, tanggung jawab, integritas, peduli, bermoral, tegas, kompeten, transparan dan bijaksana. Selain hal tersebut, faktor-faktor yang dapat menurunkan tingkat kepercayaan terhadap para elit politik erat kaitannya dengan persepsi partisipan terhadap kebohongan, korupsi, bermasalah, mementingkan diri sendiri, tidak kompeten, berkasus, tidak bertanggung jawab, menyalahgunakan kekuasaan, malas, kurang transparan dan tidak tegas.

\section{Saran}

Berdasarkan pada hasil penelitian maka saran yang dapat diberikan adalah; pertama, bagi para elit politik diharapkan mampu memberikan gambaran akan karakter yang sesuai dengan hasil penelitian agar kepercayaan terhadap elit politik selalu terjaga dengan baik. Dengan adanya kepercayaan yang baik antara elit politik dan masyarakat diharapkan menjadi modal dasar yang baik dalam pembangunan negara. Kedua, bagi peneliti selanjutnya diharapkan mampu melakukan perbaikan dalam jumlah partisipan yang terlibat dengan menggunakan pendekatan randomisasi serta rasio kriteria partisipan (pendidikan, jenis kelamin, usia dan lain-lain) agar dapat dibuat lebih seimbang. Dengan adanya perbaikan jumlah partisipan dengan menggunakan randomisasi dapat memberikan jumlah partisipan yang bisa mewakili populasi dengan baik yaitu masyarakat di Jakarta. Selain itu, rasio kriteria partisipan yang seimbang dapat memberikan gambaran yang lebih mendalam terkait dengan pembahasan. Ketiga, hasil penelitian yang ada masih bersifat subyektif dengan pendekatan kualitatif dan perlu dilakukan penelitian lanjutan yang bersifat kuantitatif dengan mengembangkannya menjadi skala psikologis dan melakukan pengujian. 


\section{Kepustakaan}

Afrido, R. (2012, 22 Maret). Mengapa pilgub DKI jadi pusat perhatian?. Okezone. Diunduh dari: http://news. okezone.com/read/2012/03/22/437/5981 11/mengapa-pilgub-dki-jadi-pusatperhatian tanggal 10 April 2015.

Antikorupsi.org. (2015). Buruknya keterbukaan informasi parpol. Diunduh dari: http://www.antikorupsi.org/id/content /buruknya-keterbukaan-informasiparpol tanggal 9 November 2015.

Banerjee, S., Bowie, N. E., \& Pavone, C. (2006). An ethical analysis of trust relationship. In R. Bachmann \& A. Zaheer (Eds). Handbook of trust research (pp.303-317). United Kingdom: Edward Elgar Publishing.

Blind, P. K. (2006). Building trust in government in the twenty first century: review of literature and emerging issues. Diunduh dari: http://unpan1.un.org/ intradoc/groups/public/documents/un /unpan025062.pdf tanggal 10 Maret 2015.

Chang, E. C. C., \& Chu, Y. H. (2006). Corruption and trust: Exceptionalism in Asian Democracies?. The Journal of Politics, 68(2), 259-271. Diunduh dari: http://www.ginareinhardt.com/wpcontent/uploads/2012/01/Chang-ChuCorruption-and-Trust.pdf tanggal 10 November 2015.

Cho, J. Y., \& Lee, E-H. (2014). Reducing confusion about grounded theory and qualitative content analysis: Similarities and differences. Diunduh dari: http://www.nova.edu/ssss/QR/QR19/c ho64.pdf tanggal 15 April 2015.

Christensen, T., \& Laegreid, P. (2002). Importance of service satisfaction, political factors and demography. Diunduh dari:
http://www.ub.uib.no/elpub/rokkan/N /N18-02.pdf tanggal 20 April 2015.

Colquitt, J. A., Scott, B. A., \& LePine, J. A. (2007). Trust, trustworthiness, and trust propensity: A meta-analytic test of their unique relationships with risk taking and job performance. Journal of Applied Psychology, 92(4), 909-927. http://dx.doi.org/10.1037/0021-9010.92. 4.909 .

Creswell, J. W. (2005). Research design: qualitive, quantitative, and mixed methods approaches (third edition). United States of America: Sage Publications.

Dalton, R. J. (2005). The social transformation of trust in government. International Review of Sociology, 15(1), 13$154 . \quad$ http://dx.doi.org/10.1080/ 03906700500038819.

Delgado, M. R., Frank, H. R., \& Phelps, E. A. (2005). Perceptions of moral character modulate the neural systems of reward during the trust game. Nature Neuroscience, 8(11), 1611-1618. http://dx.doi.org/10.1038/nn1575.

Diamond, L. (2007). Building trust in government by improving governance. Diunduh dari: http://stanford.edu/ ldiamond/paperssd/BuildingTrustin GovernmentUNGLobalForum.pdf tanggal 10 November 2015.

Dymek, M. (2015). Corruption, abuse of power and lack of trust in Sweden: Does NPM corrupt?. Diunduh dari: http:// www.ephemerajournal.org/sites/defau lt/files/pdfs/contribution/152dymek.pdf tanggal 10 November 2015.

Elo, S., \& Kyngäs, H. (2008). The qualitative content analysis process. Journal of Advanced Nursing, 62(1), 107-115. http://dx.doi.org/10.1111/j.13652648.2007.04569.x 
Faturochman. (2000). Dinamika psikologi dan sosial kepercayaan (The dynamics of psychology and social trust). In Supratiknya, Faturochman \& S. Haryanto (Editor). Tantangan psikologi menghadapi milenium baru. Yogyakarta: Penerbit Yayasan Pengembangan Fakultas Psikologi Universitas Gadjah Mada.

Galston, W. A., \& Kamarck, E. C. (2008). Change you can believe in needs a government you can trust. Diunduh dari: http://content.thirdway.org/ publications/133/Third_Way_Report__Trust_in_Government.pdf tanggal 10 November 2015.

Hafil, M. (2015, 9 April). Ubah perilaku politik agar dipercaya. Republika. Diunduh dari: http://www.republika. co.id/berita/nasional/politik/15/04/09/n mjou2-ubah-perilaku-politik-agardipercaya tanggal 15 April 2015.

Hanan, D. (2015, 11 April). Parpol dan persepsi publik. Kompas. Diunduh dari http://nasional.kompas.com/read/2015 /04/11/15150041/Parpol.dan.Persepsi.P ublik tanggal 9 November 2015.

Hardin. R. (2002). Trust and trustworthiness. Russel Sage Foundation: New York.

Hoffman, A. M. (2002). A conceptualization of trust in international relations. European Journal of International Relations, 8(3), 375-401. Diunduh dari: https://www.researchgate.net/profile/ Aaron_Hoffman/publication/22000953 7_A_Conceptualization_of_Trust_in_I nternational_Relations/links/0fcfd50fe d635a848e000000.pdf tanggal 5 November 2015.

Hultsch, D. F., MacDonald S. W. S., Hunter, M. A., Maitland, S. B., \& Dixon, R. A. (2002). Sampling and generalisabilty in developmental research: comparison of random and covenience samples of older adults. International Journal of Behavioral Development, 26(4), 345-359. http://dx. doi.org/10.1080/01650250143000247.

Igarashi, T., Kashima, Y., Kashima, E. S., Farsides, T., Kim, U., Strack, F., Werth, L., \& Yuki, M. (2008). Culture, trust, and social networks. Asian Journal of Social Psychology, 11, 88-101. http://dx. doi.org/10.1111/j.1467839X.2007.00246.X

Isotalus, P., \& Almonkari, M. (2014). Political scandal test trust in politicians: The case of the finnish minister who resigned because of his text messages. Diunduh dari: http://www.nordicom. gu.se/sites/default/files/kapitelpdf/nordicom_review_35_2014_2_pp._ 3-16.pdf tanggal 5 November 2015.

Jainuri. (2013, 16 Juli). Krisis moral politik politisi. Harianhaluan. Diunduh dari: http://www.harianhaluan.com/index.p hp/opini/24898-krisis-moral-politikpolitisi tanggal 9 November 2015.

Kim, U., \& Park, Y. S. (2005). Trust, relationship, and civil society in Scandinavia, and East Asia: Psychological, social and cultural analysis. Korean Journal of Psychological and Social Issues, 11, 133-161. Diunduh dari: http://www.kci.go.kr/kciportal/ci/sere ArticleSearch/ciSereArtiView.kci?sere ArticleSearchBean.artiId=ART0009459 36

Levi, M. (2015). Why we need a new theory of government. Diunduh dari: http://sites. lsa.umich.edu/polisci-cpw/wpcontent/uploads/sites/223/2015/02/mar garet_levi.pdf tanggal 5 November 2015.

Light, P. C. (2007). A government ill executed: The depletion of the federal service. Diunduh dari: https://wagner. 
nyu.edu/files/performance/illexecuted. pdf tanggal 10 November 2015.

Morris, S. D., \& Klesner, J. L. (2010). Corruption and trust: Theoritical considerations and evidence from mexico. Comparative Political Studies, 43(10), 1258-1285. http://dx.doi.org/ 10.1177/0010414010369072.

Neumann, M., Srbljinovic, A., \& Schatten, M. (2014). Trust me i know what I'am doing: Competence fields as a means of establishing political leadership. European Quarterly of Political Attitudes and Mentalities, 3(2), 18-33. Diunduh dari: https://bib.irb.hr/datoteka/ 694921.EQPAM-Vol3No2April2014Neumann_Srbljinovic_SchattenCCU.pdf pada tanggal 5 November 2015.

Onwuegbuzie, A. J., \& Collins, K. M. T. (2007). “A typology of mixed methods sampling designs in social science research". The Qualitative Report, 12(2), 281-316. Diunduh dari: http://www. nova.edu/ssss/QR/QR12-

2/onwuegbuzie2.pdf pada tanggal 5 April 2015.

Oosterhof, N. N., \& Todorov, A. (2009). Shared perceptual basis of emotional expressions and trustworthiness impressions from faces. Emotion, 9(1), 128-133.

http://dx.doi.org/10.1037/a0014520.

Popescu, A-I. (2015). Financing democracy or corruption? Political party financing in the EU'S southeastern and eastern member states. Diunduh dari: http:// www.ceswp.uaic.ro/articles/CESWP20 15_VII2A_POP.pdf tanggal 9 November 2015

Sahaar, S. (2014). A survei on young voters trust towards the campaign of janji ditepati before $13^{\text {th }}$ general election. Social and Behavioral Sciences, 155, 442-
447. Diunduh dari: http:// ac.elscdn.com/S1877042814057851/1-s2.0S1877042814057851-main.pdf? tid=04faa3aa-bdd1-11e5-8df200000aacb35e\&acdnat $=1453114293$ _5eb 423efbb42d0216be2a0323984a768 tanggal 9 November 2015.

Sandelowski, M., \& Barosso, J. (2003). Classifying the findings in qualitative studies. Qualitative Health Research, 13(7), 905-923. http://dx.doi.org/ 10.1177/1049732303253488.

Saut, P. D. (2013, 7 Juli). Survei LSI: 52\% publik nilai elit politik tak bisa jadi teladan. Detik. Diunduh dari: http:// news.detik.com/read/2013/07/07/15430 8/2294911/10/2/survei-lsi-52--publiknilai-elite-politik-tak-bisa-jadi-teladan tanggal 10 April 2015.

Simpson, J. A. (2007). Psychological foundations of trust. Association of Psychological Science, 16(5), 264-268. Diunduh dari: https://apps.cla.umn. edu/directory/items/publication/28662 6.pdf tanggal 9 November 2015.

Solé-Ollé, A., \& Sorribas-Navarro, P. (2014). Does corruption erode trust in government? Evidence from a recent surge of local scandals in Spain. Diunduh dari http://poseidon01.ssrn.com/delivery.p hp?ID=4680650990840000170050001010 0012007400203300905808905307309010 0071090005069070121090056119012045 1180560060220310180640241261130500 0403305805908003003108611207307108 5059080122024119101023018089004109 1091121071110040040930861181030650 13076104005029029\&EXT=pdf tanggal 9 November 2015.

Solomon, R. C., \& Flores, F. (2001). Building trust in bussiness, politics, relationships and life. Oxford University Press: New York. 
Stanley, D. A., Hessner, P. S., Banaji, M. R., \& Phelps, E. A. (2011). Implicits race attitudes predicts trustworthiness judgments and economic trust decisions. Proocedings of The National Academy of Sciences, 108(19), 7710-7715. Diunduh dari: http://www.pnas.org/ content/108/19/7710.full.pdf tanggal 15 April 2015.

Surbakti, R. (1999). Memahami ilmu politik. Penerbit PT. Gramedia Widiasarana Indonesia, Jakarta.

Tanis, M., \& Postmes, T. (2005). Short communication a social identity approach to trust: Interpersonal perception, group membership and trusting behaviour. European Journal of Social Psychology Eur. J. Soc. Psychology, 35, 413-424. http://dx.doi.org/10.1002/ ejsp.256.

Twymann, M., Harvey, N., \& Harries, C. (2008). Trust in motives, trust in competence: Separate factors determining the effectiveness of risk communication. Judgment and Decision Making,
3(1), 111-120. Diunduh dari: http:// www.sjdm.org/ baron/journal/bb10.p df pada tanggal 9 November 2015.

Van Biezen, I. (2003). Financing political parties and election campaigns-guidelines. Diunduh https://www.coe.int/t/dghl/ monitoring/greco/evaluations/round3/ Financing_Political_Parties_en.pdf tanggal 2 Desember 2015.

Van de Walle, S. (2008). Perceptions of corruption as distrust? Cause and effect in attitudes towards government. In L. Huberts, C. Jurkiewicz, \& J. Maesschalck (eds.). Ethics and integrity and the politics of governance (pp.215236). Cheltenham: Edward Elgar.

Viklund, M., \& Sjöberg, L. (2008). An expectancy-value approach to determinants of trust. Journal of Applied Social Psychology, 38(2), 294-313. http://dx.doi.org/10.1111/j.15591816.2007.00306.x.

Yamagishi, T. (2011). Trust: The evolutionary game of mind and society. Springer: Tokyo. 